\title{
Synthesis and Characterization of $\mathrm{Zr}_{2} \mathrm{Al}_{3} \mathrm{C}_{4}$ Thin Films
}

Chung-Chuan Lai†, Mark D. Tucker ${ }^{*}$, Jun Lu, Jens Jensen, Grzegorz Greczynski, Per Eklund, Johanna Rosen

Thin Film Physics Division, Department of Physics, Chemistry and Biology (IFM), Linköping University, SE-581 83 Linköping, Sweden

* Current affiliation: Department of Physics and Astronomy, Curtin University, Perth WA 6102, Australia

† Corresponding author: Chung-Chuan Lai (E-mail address: chula@ifm.liu.se)

\begin{abstract}
$\mathrm{Zr}_{2} \mathrm{Al}_{3} \mathrm{C}_{4}$ is an inherently nanolaminated carbide where layers of $\mathrm{ZrC}$ alternate with layers of $\mathrm{Al}_{3} \mathrm{C}_{2}$. Characterization of bulk samples has shown it has improved damage tolerance and oxidation resistance compared to its binary counterpart $\mathrm{ZrC}$. Though a potential candidate for coatings applied for use in harsh environments, thin films of $\mathrm{Zr}_{2} \mathrm{Al}_{3} \mathrm{C}_{4}$ have not been reported. We have synthesized epitaxial $\mathrm{Zr}_{2} \mathrm{Al}_{3} \mathrm{C}_{4}$ thin films by pulsed cathodic arc deposition from three elemental cathodes, and have studied the effect of incident atomic flux ratio, deposition temperature, and choice of substrate on material quality. X-ray diffraction analysis showed that $\mathrm{Zr}_{2} \mathrm{Al}_{3} \mathrm{C}_{4}$ of the highest structural quality was obtained for growth on $4 \mathrm{H}-\mathrm{SiC}(001)$ substrate at $800{ }^{\circ} \mathrm{C}$. Also, suppression of competing phases could be achieved on $\alpha-\mathrm{Al}_{2} \mathrm{O}_{3}(001)$ at elevated substrate temperatures. Very similar growth behavior to that of the well-known $M_{n+1} A X_{n}$ phases Al supersaturation, binary carbide intergrowth and high sensitivity to choice of substrate - indicates a strong connection between the two families of materials, despite their differences in structure and in chemistry.
\end{abstract}

Keywords: Thin film; Cathodic arc deposition; Zr2Al3C4; Nanolaminate; Zirconium carbide 


\section{Introduction}

The binary transition metal carbides ( $M \mathrm{C}$, where $M$ is a transition metal) have been thoroughly studied since the 1930s, in part motivated by attention from industry [1]. MCs are generally harder, ore refractory, and more chemically stable than their metallic counterparts, while remaining electrically and thermally conductive, but they are brittle [2]. Today, they are commonly utilized as reinforcement in composites (e.g.WC-Co [3]) and protective coatings (e.g. $\mathrm{TiC}, \mathrm{NbC}, \mathrm{CrC}$ [4]).

In order to improve the performance of binary carbides at elevated temperature, a third component can be introduced, forming ternary transition metal carbides $(M A \mathrm{C}$, where $A$ is typically a group 13-16 element). Commonly, the $A$ element is $\mathrm{Al}$, as in $\mathrm{Ti}_{2} \mathrm{AlC}, \mathrm{Ti}_{3} \mathrm{AlC}_{2}$ and $\mathrm{Zr}_{2} \mathrm{Al}_{3} \mathrm{C}_{4}$, causing improvement in high temperature oxidation resistance by the formation of a continuous and dense oxygen diffusion barrier of alumina on the surface [5-10].

A class of ternary and quaternary carbides have inherently nanolaminated structures with alternating transition metal carbide layers $(M C)$ and $A$-element-containing layers $(A$ or $A \mathrm{C})$ along one crystal axis [11]. They have several different formulas $M_{n+1} A \mathrm{C}_{n},(M \mathrm{C})_{n}\left(A_{3} \mathrm{C}_{2}\right)$, and $(M \mathrm{C})_{n}\left(A_{4} \mathrm{C}_{3}\right)$, where $n$ is $1-3[12,13]$, for example $\mathrm{Ti}_{3} \mathrm{AlC}_{2},(\mathrm{ZrC})_{2}\left(\mathrm{Al}_{3} \mathrm{C}_{2}\right)$ or $\mathrm{Zr}_{2} \mathrm{Al}_{3} \mathrm{C}_{4}$, and $(\mathrm{HfC})_{3}\left(\mathrm{Al}_{4} \mathrm{C}_{3}\right)$ or $\mathrm{Hf}_{3} \mathrm{Al}_{4} \mathrm{C}_{6}[14-16]$. They commonly have superior mechanical properties, such as higher tolerance against damage and increased machinability, to their binary carbide counterparts $[14,17,18]$.These properties originate from their layered structures.

$\mathrm{Zr}_{2} \mathrm{Al}_{3} \mathrm{C}_{4}$ was first reported in bulk form in 1980 by Schuster and Nowotny [19], but detailed studies on properties of this phase were not conducted until the 2000s. The material exhibits high electrical conductivity $(1.10 \mu \Omega \mathrm{m})$ along with higher stiffness and toughness than $\mathrm{ZrC}[20]$ and an improved high temperature oxidation resistance. Because of these properties, Zhou et al. proposed 
$\mathrm{Zr}_{2} \mathrm{Al}_{3} \mathrm{C}_{4}$ as a potential candidate for applications such as reinforcing composite for metals [21] and protective conducting coatings in harsh environments [13]. However, thin film synthesis of inherently nanolaminated phases in the $\mathrm{Zr}-\mathrm{Al}-\mathrm{C}$ system, including $\mathrm{Zr}_{2} \mathrm{Al}_{3} \mathrm{C}_{4}$, has not yet been reported.

Here, we report synthesis of $\mathrm{Zr}_{2} \mathrm{Al}_{3} \mathrm{C}_{4}$ thin films by pulsed cathodic arc deposition. Samples deposited with different $\mathrm{Al}$ to $\mathrm{Zr}$ and $\mathrm{C}$ to $\mathrm{Zr}$ incident atomic flux ratios, on different substrates $(\alpha$ $\mathrm{Al}_{2} \mathrm{O}_{3}(001), \mathrm{MgO}(111), 4 \mathrm{H}-\mathrm{SiC}(001)$, and yttria-stabilized-zirconia (YSZ) (111)), and at different substrate temperatures $\left(700^{\circ} \mathrm{C}, 750{ }^{\circ} \mathrm{C}, 800^{\circ} \mathrm{C}\right.$ and $\left.900{ }^{\circ} \mathrm{C}\right)$ were investigated. Epitaxial growth of $\mathrm{Zr}_{2} \mathrm{Al}_{3} \mathrm{C}_{4}$ was achieved on $4 \mathrm{H}-\mathrm{SiC}$ substrates, and suppression of competing phases could also be achieved on $\alpha-\mathrm{Al}_{2} \mathrm{O}_{3}$ at elevated substrate temperatures.

\section{Experimental details}

\subsection{Thin film synthesis}

All depositions were made in a high current pulsed cathodic arc system equipped with three cylindrical cathodes $(\varnothing=25 \mathrm{~mm})$, slightly tilted to allow plasma flux into a copper solenoid filter for macroparticle removal. This method has previously been used for synthesis of laminated carbides [22-24], see Ref. [25] for details about the deposition system. Each cathode is surrounded by a cylindrical anode and is triggered using a center-positioned tungsten trigger pin electrically insulated from the cathode. During deposition, the cathodes are fired separately, at a base pressure of around $10^{-7}$ mbar.

The samples were deposited from three elemental cathodes, $\mathrm{Zr}, \mathrm{Al}$ and $\mathrm{C}$, with purities of 99.9\%, 99.99\% and 99.99\%, respectively (Testbourne Ltd.), using an arc current of $1.5 \mathrm{kA}$ and a pulsed 
frequency of $11 \mathrm{~Hz}$. The width of one pulse for the $\mathrm{Zr}, \mathrm{Al}$ and $\mathrm{C}$ cathodes were 350, 250 and 500 $\mu \mathrm{s}$, respectively.

The incoming atomic flux ratio was controlled by triggering the three cathodes in a repeating pulse sequence and varying the number of pulses to each cathode in the sequence. In initial calibrations the deposition rate from each cathode was determined by attaining density and thickness from Xray reflectivity (XRR) measurements on samples deposited on $\mathrm{Si}(100)$ substrates at room temperature. This information was used to determine the atomic flux ratio incident on the substrate (or the 'flux ratio') for a chosen pulse sequence.

The substrates used in this work were $\alpha-\mathrm{Al}_{2} \mathrm{O}_{3}(001), \mathrm{MgO}(111), 4 \mathrm{H}-\mathrm{SiC}(001)$, and yttriastabilized zirconia (111) (YSZ, $\mathrm{Zr}_{0.92} \mathrm{Y}_{0.08} \mathrm{O}_{2}$ ). All substrates were cleaned in an ultrasonic bath for 10 min each in acetone then isopropanol, and were blown dry with $\mathrm{N}_{2}$. The substrate was kept for $15 \mathrm{~min}$ at the deposition temperature before material synthesis to ensure a uniform temperature over the sample. One thin film sample, presented in Section 3.1, was deposited on $4 \mathrm{H}-\mathrm{SiC}(001)$ with a thickness of about $200 \mathrm{~nm}$ for better statistics in composition analysis, see Section 2.2. The other samples presented were about $20 \mathrm{~nm}$ thick according to deposition rate calibration prior to the sample deposition.

\subsection{Thin film characterization}

XRR and X-ray diffraction (XRD) patterns were acquired in an X-ray diffractometer (Empyrean, PANalytical B.V.) using $\mathrm{CuK} \alpha$ radiation and a $\mathrm{Ge}(220)$ crystal hybrid monochromator on the incident side and a parallel plate collimator (PPC) on the receiving side. An extra equatorial 0.1 mm collimator slit was inserted between the PPC and the detector when acquiring XRR patterns, which later were fitted within X'Pert Reflectivity software (Ver. 1.3, PANalytical B.V.) to obtain 
the density and thickness of the calibration samples. XRD was used for phase identification and analysis of crystal orientation.

The microstructure of the films was characterized using high resolution transmission electron microscopy (HR-TEM) on cross cross sectional samples in a FEI Tecnai G2 microscope operated with an acceleration voltage of $200 \mathrm{kV}$.

Time-of-flight elastic recoil detection analysis (TOF-ERDA) was performed on the thicker sample to obtain an average composition from a larger sampling volume and a more reliable quantification of the lighter elements, such as $\mathrm{C}, \mathrm{O}$ and $\mathrm{N}$.

\section{Results and Discussion}

\subsection{Characterization of $\mathrm{Zr}_{2} \mathrm{Al}_{3} \mathrm{C}_{4}$ thin films}

Fig. 1(a) is a $\theta-2 \theta \mathrm{XRD}$ pattern of a $\mathrm{Zr}_{2} \mathrm{Al}_{3} \mathrm{C}_{4}$ thin film deposited on $4 \mathrm{H}-\mathrm{SiC}(001)$ at $800{ }^{\circ} \mathrm{C}$ with flux ratio $(\mathrm{Al} / \mathrm{Zr})=5.75$ and $(\mathrm{C} / \mathrm{Zr})=1.67$. The six diffraction peaks labeled $\mathrm{s}$ in Fig. 1 (a) are the basal planes $(00 l)$ of the SiC substrate [26]. The eight peaks at around $7.9^{\circ}, 15.9^{\circ}, 24.2^{\circ}, 32.3^{\circ}$, $40.7^{\circ}, 58.4^{\circ}, 67.7^{\circ}$ and $77.3^{\circ}$ share the same least common multiple of interplanar spacing $(d$ spacing) $\sim 11.1 \AA$, and can be assigned to diffraction from the basal planes $(00 l)$ of the $\mathrm{Zr}_{2} \mathrm{Al}_{3} \mathrm{C}_{4}$ phase with a $c$ parameter of $\sim 22.2 \AA$ [27]. The additional peaks at $\sim 33.0^{\circ}$ and $\sim 69.1^{\circ}$ are the 111 and 222 peaks of cubic $\operatorname{ZrC}_{x}(0.67 \leq x \leq 1.0)$ [28]. The inset of Fig. 1(a) is an in-plane $\left(\psi \sim 90^{\circ}\right)$ $\theta-2 \theta$ XRD pattern over the range $2 \theta=52-62^{\circ}$ showing 110 diffraction of $\mathrm{Zr}_{2} \mathrm{Al}_{3} \mathrm{C}_{4}$ and the substrate. From the position of $\mathrm{Zr}_{2} \mathrm{Al}_{3} \mathrm{C}_{4}(110)$ its $a$ parameter can be determined to be $\sim 3.34 \AA$, while the asymmetric shape of the peak indicates an overlap of a $\mathrm{ZrC}_{x} 220$ peak with lower intensity.

Fig. 1 (b) shows $\varphi$-scans acquired at $2 \theta=65.702^{\circ}, 53.040^{\circ}$ and $58.560^{\circ}$ and at fixed tilt angle $\psi$ from the surface normal of the sample, with $\psi=68.50^{\circ}, 55.50^{\circ}$ and $63.00^{\circ}$, which correspond to 
(a)

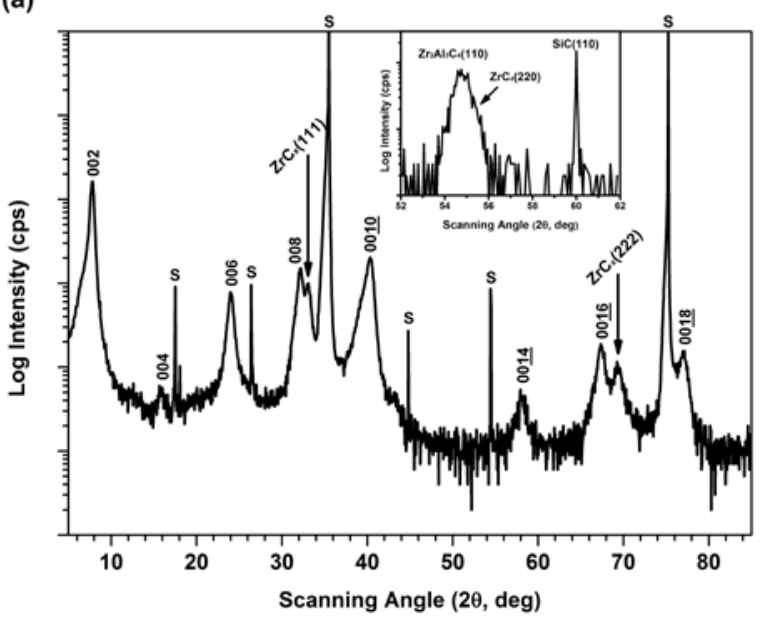

(b)

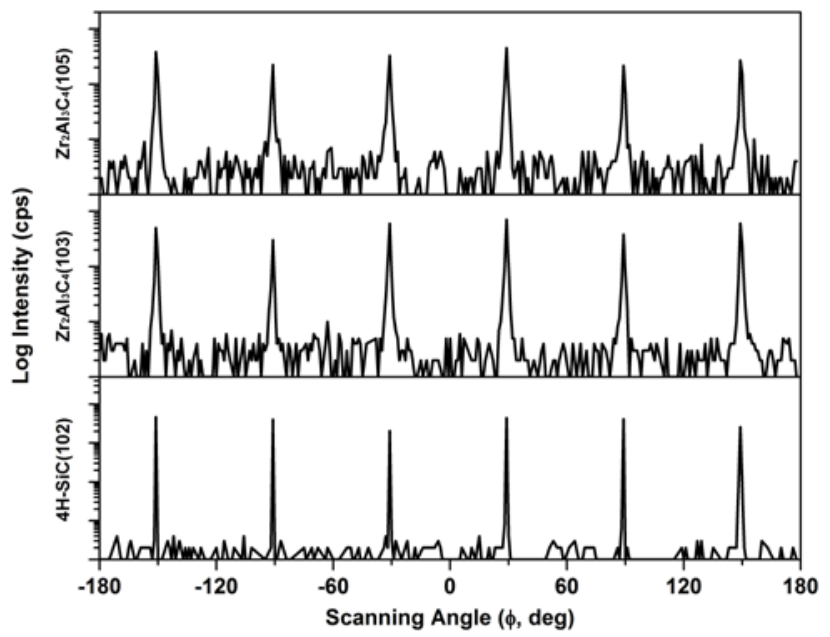

Fig. 1. (a) $\theta-2 \theta$ XRD patterns of a $\mathrm{Zr}_{2} \mathrm{Al}_{3} \mathrm{C}_{4}$ thin film grown on $4 \mathrm{H}-\mathrm{SiC}(001)$ at $800{ }^{\circ} \mathrm{C}$. The inset is an in-plane $\theta-2 \theta$ XRD pattern over the range $2 \theta=52-62^{\circ}$. (b) Tilted $\varphi$-scan XRD patterns on the $\mathrm{Zr}_{2} \mathrm{Al}_{3} \mathrm{C}_{4}(103), \mathrm{Zr}_{2} \mathrm{Al}_{3} \mathrm{C}_{4}(105)$ and $4 \mathrm{H}-\mathrm{SiC}(102)$ planes of the sample shown in (a).

diffraction from $\mathrm{Zr}_{2} \mathrm{Al}_{3} \mathrm{C}_{4}(103), \mathrm{Zr}_{2} \mathrm{Al}_{3} \mathrm{C}_{4}(105)$ and $4 \mathrm{H}-\mathrm{SiC}(102)$ planes, respectively. The six peaks separated by $60^{\circ}$ in all three scans share the same $\varphi$ peak positions, indicating the epitaxial relation $\mathrm{Zr}_{2} \mathrm{Al}_{3} \mathrm{C}_{4}[100] \| 4 \mathrm{H}-\mathrm{SiC}[100]$ and $\mathrm{Zr}_{2} \mathrm{Al}_{3} \mathrm{C}_{4}[001] \| 4 \mathrm{H}-\mathrm{SiC}[001]$.

TOF-ERDA quantification of the sample investigated in Fig. 1 showed average atomic concentrations of $(\mathrm{Zr}, \mathrm{Al}, \mathrm{C}, \mathrm{O}, \mathrm{N})=(29.3,26.8,43.1,0.6,0.1)$ at.\%, respectively. Traces of $\mathrm{Ti}$ and Hf, which are both common impurities found in $\mathrm{Zr}$ cathodes [29], were also observed but at levels below the quantification limit. This data shows that, relative to the composition of $Z_{2} \mathrm{Al}_{3} \mathrm{C}_{4}$, the film is deficient in $\mathrm{Al}$, explaining the presence of $\mathrm{ZrC}_{x}$ formed from the excess $\mathrm{Zr}$ and $\mathrm{C}$. The nearly 4 times higher $(\mathrm{Al} / \mathrm{Zr})$ flux ratio than the stoichiometry of $\mathrm{Zr}_{2} \mathrm{Al}_{3} \mathrm{C}_{4}$ phase, as well as the $\mathrm{Al}$ deficiency observed in this film, were likely due to high sublimation rate and low sticking 
coefficient of $\mathrm{Al}$ at $800^{\circ} \mathrm{C}$. The known higher sputter yield of $\mathrm{Al}$ compared to $\mathrm{C}$ may also lead to a high rate of $\mathrm{Al}$ resputtering by the relatively massive $\mathrm{Zr}$ species.

Figs. 2 (a) and (b) are TEM images of the sample investigated in Fig. 1, acquired along the [110] zone axis. Fig. 2 (a) shows a layered pattern with a vertical period of $\sim 22.2 \AA$, which matches with the $c$ lattice parameter of $\mathrm{Zr}_{2} \mathrm{Al}_{3} \mathrm{C}_{4}$. The inset is a SAED pattern acquired along the same zone axis and two diffraction points closest to the origin are indexed. Fig. 2 (b) shows an overview image of the film, where a $\mathrm{ZrC}_{x}$ intergrowth layer can be observed in between a defect-rich $\mathrm{Zr}_{2} \mathrm{Al}_{3} \mathrm{C}_{4}$ layer and a $\mathrm{Zr}_{2} \mathrm{Al}_{3} \mathrm{C}_{4}$ layer with tilted grains. These tilted grains grew on the defect-rich and rough
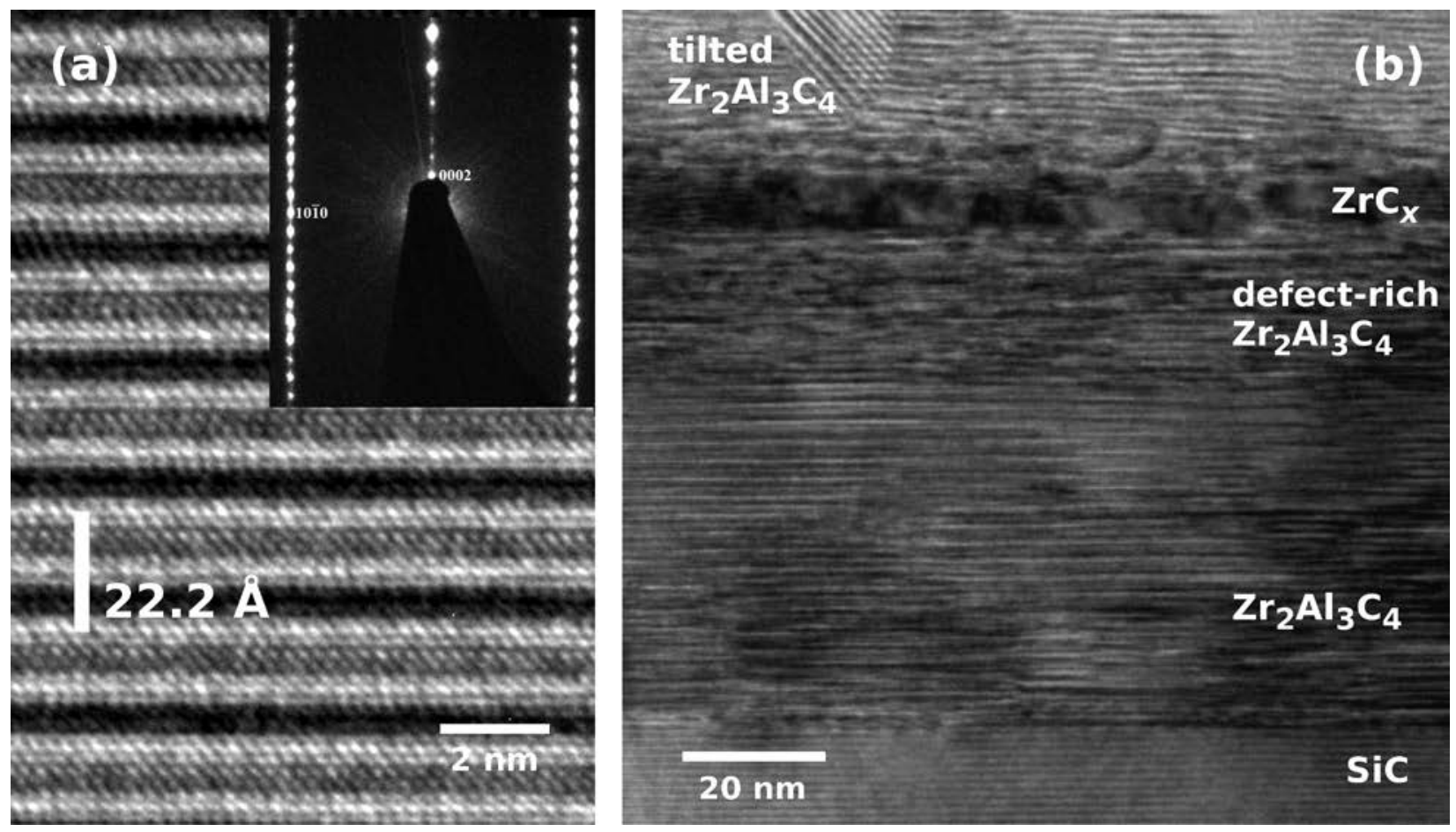

Fig. 2. HR-TEM images acquired along the [110] zone axis of the $\mathrm{Zr}_{2} \mathrm{Al}_{3} \mathrm{C}_{4}$ sample shown in Fig. 1. (a) The multilayer structure of the $\mathrm{Zr}_{2} \mathrm{Al}_{3} \mathrm{C}_{4}$ crystal. The inset is the corresponding SAED pattern. (b) An overview image showing different $\mathrm{Zr}_{2} \mathrm{Al}_{3} \mathrm{C}_{4}$ layers and $\mathrm{ZrC}$ intergrowth. 
surface of the underlying $\mathrm{ZrC}_{x}$ layer, which promoted the nucleation of other planes than the basal planes, normally the planes with the lowest surface energy. This shows that epitaxy of $\mathrm{Zr}_{2} \mathrm{Al}_{3} \mathrm{C}_{4}$ strongly depends on the structural quality of the surface where nucleation takes place.

Lin et al. have previously observed the intergrowth of $\mathrm{ZrC}_{x}$ phase in $\mathrm{Zr}_{2} \mathrm{Al}_{3} \mathrm{C}_{4}$ and related nanolaminated phases with high-resolution scanning transmission electron microscopy [30]. Similarly, observations of binary carbide intergrowth have been reported in other thin films of layered ternary carbides, for example $\mathrm{Ti}_{2} \mathrm{AlC}$ and $\mathrm{Ti}_{3} \mathrm{SiC}_{2}$, where they were explained by a high sensitivity to local composition changes in such ternary phases [31,32]. Here, the onset of $\mathrm{Al}$ deficiency during the deposition can possibly be related to the transition into the defect rich $\mathrm{Zr}_{2} \mathrm{Al}_{3} \mathrm{C}_{4}$ layer. The $\mathrm{ZrC}_{x}$ layer started to nucleate when the $\mathrm{Al}$ concentration was too low to form the $\mathrm{Zr}_{2} \mathrm{Al}_{3} \mathrm{C}_{4}$ phase, and the tilted $\mathrm{Zr}_{2} \mathrm{Al}_{3} \mathrm{C}_{4}$ layer started to grow on the $\mathrm{ZrC}_{x}$ layer as $\mathrm{Al}$ concentration was increased again.

\subsection{Effect of the flux ratio}

Fig. 3 (a) shows $\theta-2 \theta$ XRD patterns of three samples grown on $\alpha-\mathrm{Al}_{2} \mathrm{O}_{3}(001)$ with different $(\mathrm{Al} / \mathrm{Zr})$ flux ratios. The sharp peaks at $20.5^{\circ}$ and $41.7^{\circ}$ are $\alpha-\mathrm{Al}_{2} \mathrm{O}_{3} 003$ and 006 peaks respectively [26]. The peaks from $\mathrm{Zr}_{2} \mathrm{Al}_{3} \mathrm{C}_{4}$ basal planes (at similar positions as in Fig. 1 (a)) are marked with dashed lines and labeled $00 l, l=2,4,6 \ldots$, here and in Fig. 3 (b) and 4. The $\mathrm{ZrC}_{x} 111$ and 222 peaks are again observed at $33.0^{\circ}$ and $69.1^{\circ}$. The peaks at $38.0^{\circ}$ and $81.0^{\circ}$, sharing a common multiple of $d$

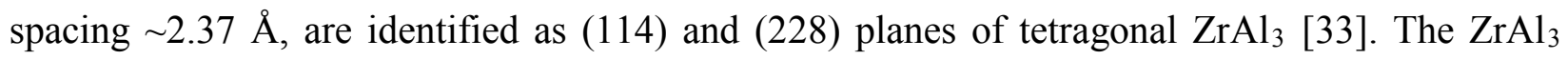
intermetallic phase is a commonly found phase in the synthesis of $\mathrm{Zr}-\mathrm{Al}-\mathrm{C}$ ternary carbides, such as $\mathrm{Zr}_{2} \mathrm{Al}_{3} \mathrm{C}_{4}, \mathrm{Zr}_{3} \mathrm{Al}_{3} \mathrm{C}_{5}$ and $\mathrm{Zr}_{2} \mathrm{Al}_{4} \mathrm{C}_{5}$ [20,34-36]. 

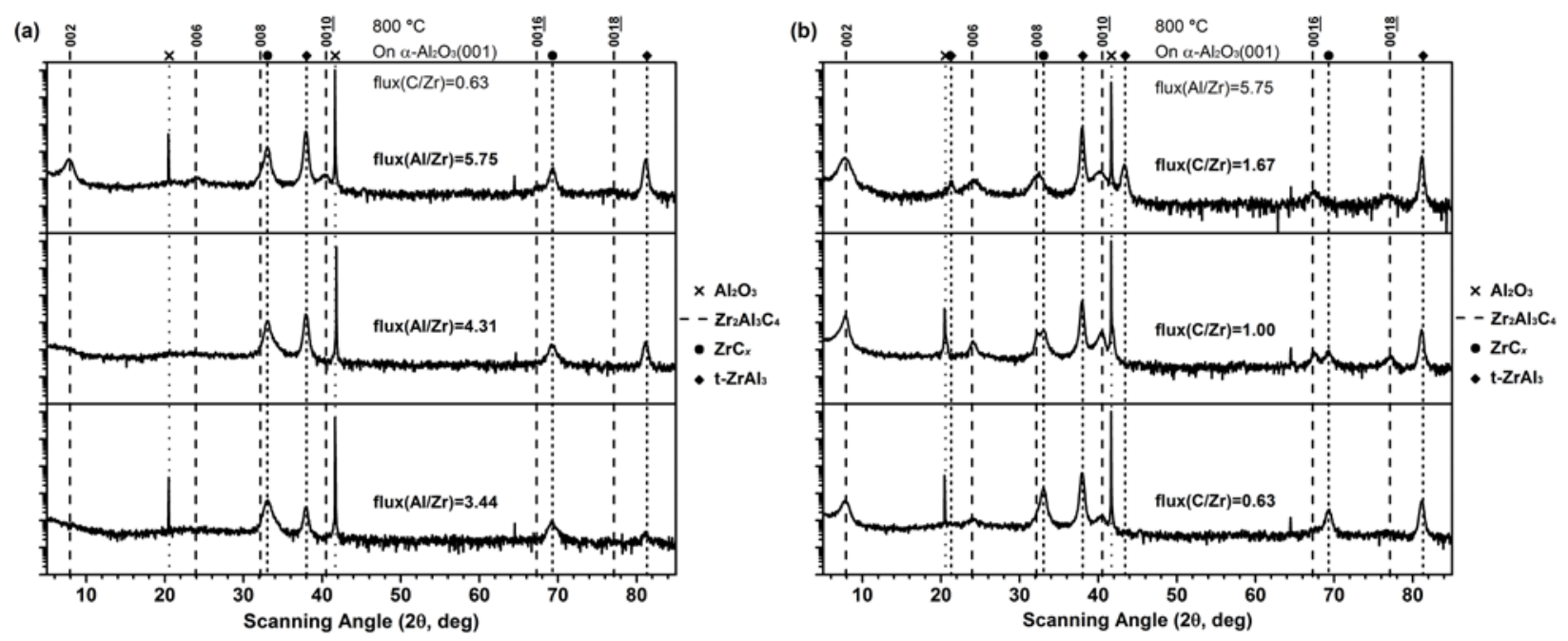

Fig. 3. $\theta-2 \theta$ XRD patterns of $\mathrm{Zr}_{2} \mathrm{Al}_{3} \mathrm{C}_{4}$ grown on $\alpha-\mathrm{Al}_{2} \mathrm{O}_{3}(001)$ at $800{ }^{\circ} \mathrm{C}$ with (a) different $(\mathrm{Al} / \mathrm{Zr})$ incident atomic flux ratios and (b) different $(\mathrm{C} / \mathrm{Zr})$ incident atomic flux ratios.

In Fig. 3 (a), the intensities of the $\mathrm{Zr}_{2} \mathrm{Al}_{3} \mathrm{C}_{4}$ peaks increase with increasing $(\mathrm{Al} / \mathrm{Zr})$ flux ratio, which indicates a preferable growth condition for $\mathrm{Zr}_{2} \mathrm{Al}_{3} \mathrm{C}_{4}$ crystals with higher $\mathrm{Al}$ flux. It is worth noting that a clear trace of $\mathrm{Zr}_{2} \mathrm{Al}_{3} \mathrm{C}_{4} 002$ peak appears when the flux ratio $(\mathrm{Al} / \mathrm{Zr})=5.75$, which is more than 3 times that of $(\mathrm{Al} / \mathrm{Zr})=1.50$ as in the stoichiometric $\mathrm{Zr}_{2} \mathrm{Al}_{3} \mathrm{C}_{4}$. This is similar to our observation in Section 3.1, where a high or possibly supersaturating $\mathrm{Al}$ in the deposition flux is needed for nucleation and growth of $\mathrm{Zr}_{2} \mathrm{Al}_{3} \mathrm{C}_{4}$ phase. When the $\mathrm{Al}$ flux is not sufficiently high, $\mathrm{ZrC}_{x}$ starts to nucleate and grow. Again, the supersaturation of the $A$ element (Al, Si...etc.) in the ternary carbide systems is often required to initiate the nucleation of the phases [11,31,32]. Notice that the $(\mathrm{C} / \mathrm{Zr})$ flux ratio is very close to 0.67 of the $\mathrm{Zr}_{3} \mathrm{AlC}_{2}$ stoichiometry, though the latter phase has not yet been reported. Even within our tested incident composition range the (Al/Zr) flux ratio varies from 0 to 5.75 , no $\mathrm{Zr}_{3} \mathrm{AlC}_{2}$ phase has been observed. 
Fig. 3 (b) shows $\theta-2 \theta$ XRD patterns of three samples grown on $\alpha-\mathrm{Al}_{2} \mathrm{O}_{3}(001)$ with varied $(\mathrm{C} / \mathrm{Zr})$ flux ratio, where similar competing phases, $\mathrm{ZrC}_{x}$ and $\mathrm{ZrAl}_{3}$, are observed as in Fig. 3 (a). It shows that the $\mathrm{Zr}_{2} \mathrm{Al}_{3} \mathrm{C}_{4}$ phase appears for a $(\mathrm{C} / \mathrm{Zr})$ flux ratio between 0.63 to 1.67 , i.e. from less than $1 / 3$ up to $5 / 6$ of the $\mathrm{Zr}_{2} \mathrm{Al}_{3} \mathrm{C}_{4}$ stoichiometry. For this wide synthesis window, improved crystal quality can be found when the $(\mathrm{C} / \mathrm{Zr})$ flux ratio approaches the ideal stoichiometry, which increases the intensity of diffraction peaks $\mathrm{Zr}_{2} \mathrm{Al}_{3} \mathrm{C}_{4} 008$ and 0010. Meanwhile, the decreasing $\mathrm{ZrC}_{x}$ and increasing $\mathrm{Zr}_{2} \mathrm{Al}_{3} \mathrm{C}_{4}$ intensity indicate that higher $\mathrm{C}$ flux stabilizes more $\mathrm{Zr}$ in $\mathrm{Zr}_{2} \mathrm{Al}_{3} \mathrm{C}_{4}$ phase.

In both Figs. 3 (a) and (b), a high (A1/Zr) flux ratio is commonly needed in order to form $\mathrm{Zr}_{2} \mathrm{Al}_{3} \mathrm{C}_{4}$, also favoring the formation of $\mathrm{ZrAl}_{3}$ phase. The almost unchanged $\mathrm{ZrAl}_{3}$ intensity when varying the $\mathrm{C}$ flux, and the increasing $\mathrm{ZrAl}_{3}$ intensity when increasing the $\mathrm{Al}$ flux indicates that the $\mathrm{Al}$ flux is a more important determinant of the presence of this competing phase. Since $\mathrm{Zr}_{2} \mathrm{Al}_{3} \mathrm{C}_{4}$ requires higher Al flux ratio to nucleate, it seems difficult to purify the ternary phase simply by varying the incident flux ratio at this temperature.

\subsection{Effect of substrate temperature}

Fig. 4 shows $\theta-2 \theta$ XRD patterns of samples deposited on $\alpha-\mathrm{Al}_{2} \mathrm{O}_{3}(001)$ with the same flux ratio, $(\mathrm{Al} / \mathrm{Zr})=5.75$ and $(\mathrm{C} / \mathrm{Zr})=1.67$, at temperatures of $700{ }^{\circ} \mathrm{C}, 750{ }^{\circ} \mathrm{C}, 800{ }^{\circ} \mathrm{C}$ and $900{ }^{\circ} \mathrm{C}$. A very low intensity $\mathrm{Zr}_{2} \mathrm{Al}_{3} \mathrm{C}_{4} 008$ peak can be observed at $700{ }^{\circ} \mathrm{C}$, which increases in intensity with increasing substrate temperature. The only competing phase observed is the $\mathrm{ZrAl}_{3}$ phase, which is dominant at lower temperatures. In the sample deposited at $900{ }^{\circ} \mathrm{C}$, the film appears highly phase pure $\mathrm{Zr}_{2} \mathrm{Al}_{3} \mathrm{C}_{4}$, with no trace of competing phases in the XRD pattern.

The observation of the increased $\mathrm{Zr}_{2} \mathrm{Al}_{3} \mathrm{C}_{4}$ phase purity at higher temperatures indicates preferred growth of the phase compared to the competing phase, $\mathrm{ZrAl}_{3}$, and is explained by increased adatom 


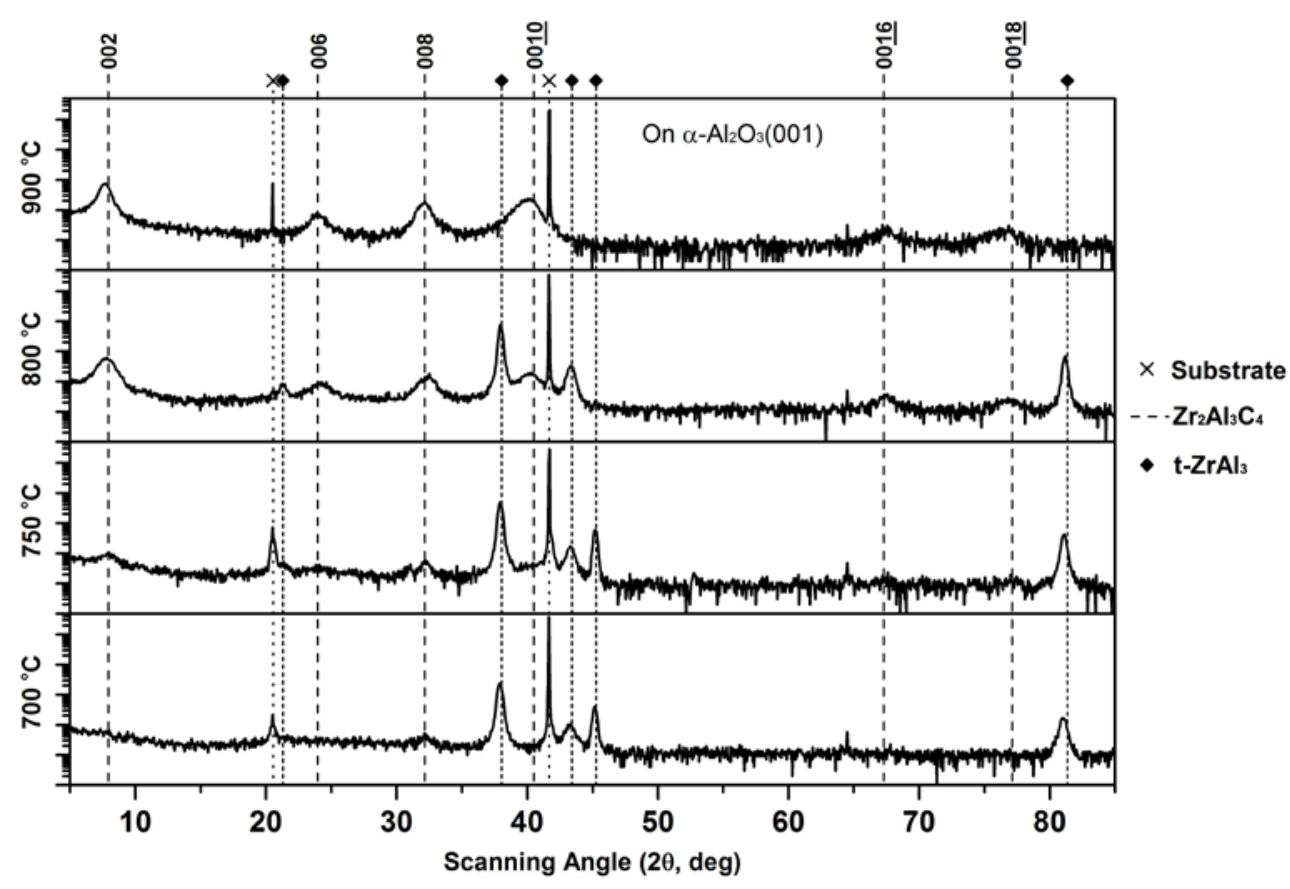

Fig. 4. $\theta-2 \theta$ XRD patterns of $\mathrm{Zr}_{2} \mathrm{Al}_{3} \mathrm{C}_{4}$ grown on $\alpha-\mathrm{Al}_{2} \mathrm{O}_{3}(001)$ substrates at four different substrate temperatures, all with the incident atomic flux ratio $(\mathrm{Al} / \mathrm{Zr})=5.75$ and $(\mathrm{C} / \mathrm{Zr})=1.67$.

mobility and diffusion. At higher temperatures, the adatoms are supplied with more thermal energy and are more kinetically mobile, which enables diffusion into possible energetically favorable sites. Therefore comparatively long range order material can be formed, such as $\mathrm{Zr}_{2} \mathrm{Al}_{3} \mathrm{C}_{4}$ compared to $\mathrm{ZrAl}_{3}$, provided that the former phase is thermodynamically stable or metastable at the deposition temperature [37]. A similar observation has been reported in bulk synthesis of $\mathrm{Zr}_{2} \mathrm{Al}_{3} \mathrm{C}_{4}$ phase where the $\mathrm{Zr}_{2} \mathrm{Al}_{3} \mathrm{C}_{4}$ and $\mathrm{Zr}_{3} \mathrm{Al}_{3} \mathrm{C}_{5}$ (another $(M \mathrm{C})_{n}\left(\mathrm{Al}_{3} \mathrm{C}_{2}\right)$ phase with $n=3$ ) phases appear above $1160{ }^{\circ} \mathrm{C}$ and the $\mathrm{ZrAl}_{3}$ phase dominates in lower temperature [20].

\subsection{Effect of Substrate Material}

Fig. 5 shows $\theta-2 \theta$ XRD patterns of samples deposited on $\alpha-\mathrm{Al}_{2} \mathrm{O}_{3}(001), \mathrm{MgO}(111), 4 \mathrm{H}-\mathrm{SiC}(001)$ and $\mathrm{YSZ}(111)$ substrates at $800{ }^{\circ} \mathrm{C}$ with the same flux ratios $(\mathrm{Al} / \mathrm{Zr})=5.75$ and $(\mathrm{C} / \mathrm{Zr})=1.67$. 


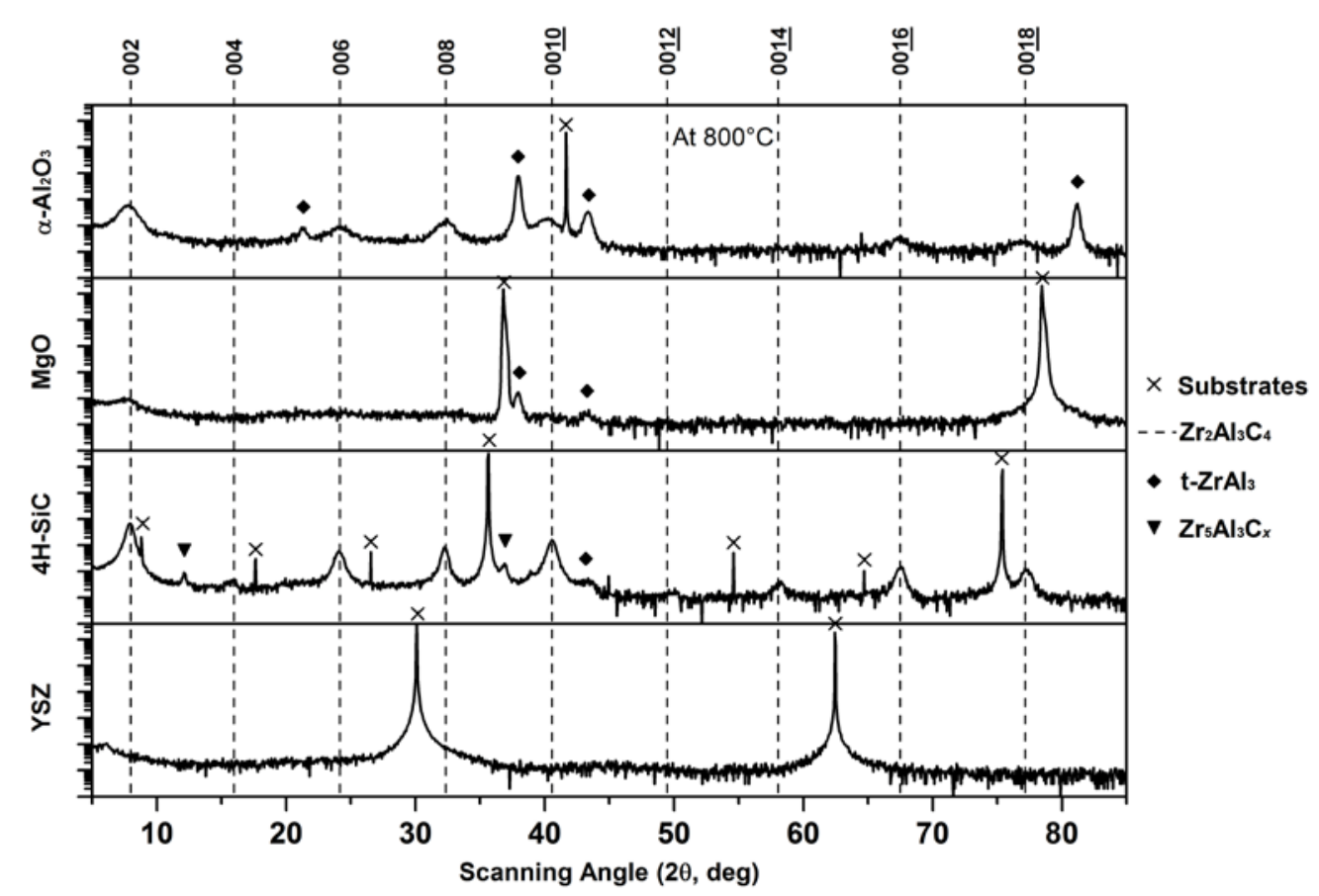

Fig. 5. $\theta-2 \theta$ XRD patterns of $\mathrm{Zr}_{2} \mathrm{Al}_{3} \mathrm{C}_{4}$ grown on $\alpha-\mathrm{Al}_{2} \mathrm{O}_{3}(001), \mathrm{MgO}(111), 4 \mathrm{H}-\mathrm{SiC}(001)$ and $\mathrm{YSZ}(111)$ substrates, all at $800^{\circ} \mathrm{C}$ and with the incident atomic flux ratio $(\mathrm{Al} / \mathrm{Zr})=5.75$ and $(\mathrm{C} / \mathrm{Zr})=1.67$.

Peaks from $\mathrm{Zr}_{2} \mathrm{Al}_{3} \mathrm{C}_{4}$ are labeled with dashed lines, while substrate and competing phases are labeled in their respective peak positions [26]. A new competing phase, identified as hexagonal $\mathrm{Zr}_{5} \mathrm{Al}_{3} \mathrm{C}_{x}$ [38], $x=0-1$, appears on the $4 \mathrm{H}-\mathrm{SiC}$ substrate. $M_{5} A_{3} \mathrm{C}_{x}$ phases are known stable in many transition element systems [37]. Several diffraction peaks from $\mathrm{Zr}_{2} \mathrm{Al}_{3} \mathrm{C}_{4}$ can be observed on $\alpha-\mathrm{Al}_{2} \mathrm{O}_{3}$ and $4 \mathrm{H}-\mathrm{SiC}$; higher $\mathrm{Zr}_{2} \mathrm{Al}_{3} \mathrm{C}_{4}$ and lower competing phase diffraction intensities are found on $4 \mathrm{H}-\mathrm{SiC}$ than on $\alpha-\mathrm{Al}_{2} \mathrm{O}_{3}$. In contrast, only a weak $\mathrm{Zr}_{2} \mathrm{Al}_{3} \mathrm{C}_{4} 002$ peak can be observed on $\mathrm{MgO}$, and there is no observation of $\mathrm{Zr}_{2} \mathrm{Al}_{3} \mathrm{C}_{4}$ on $\mathrm{YSZ}$ substrates. This indicates a strong dependence of crystal growth on the structure of the underlying substrates.

The lattice misfits $\varepsilon_{\mathrm{L}}$ of the $\mathrm{Zr}_{2} \mathrm{Al}_{3} \mathrm{C}_{4}$ phase on $\alpha-\mathrm{Al}_{2} \mathrm{O}_{3}(001), \mathrm{MgO}(111), 4 \mathrm{H}-\mathrm{SiC}(001)$ and YSZ(111) substrates can be calculated by inserting the in-plane lattice constant of the film $a_{\mathrm{f}}$ and 
the substrate $a_{\mathrm{s}}$ into the equation $\varepsilon_{\mathrm{L}}=\left(a_{\mathrm{f}} / a_{\mathrm{S}}-1\right) \times 100 \%$. The lattice misfit to the substrate is $+21.45 \%$ (sapphire), $+12.08 \%(\mathrm{MgO}),+8.69 \%(\mathrm{SiC})$ and $-8.14 \%$ (YSZ), given the lattice constant $a_{\mathrm{Zr2Al3C4}}=3.34 \AA, a_{\text {sapphire }}=2.75 \AA, a_{\mathrm{MgO}}=2.98 \AA, a_{\mathrm{SiC}}=3.07 \AA$ and $a_{\mathrm{YSZ}}=3.63 \AA[26]$. The

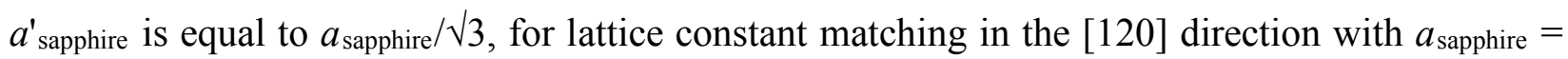
$4.76 \AA$; while $a_{\text {YSZ }}$ is an averaged value from in-plane XRD analysis of 10 YSZ substrates. Though $\alpha-\mathrm{Al}_{2} \mathrm{O}_{3}(001)$ has a relatively large lattice misfit, a domain matching epitaxy (DME) can reduce the misfit significantly down to $-0.6 \%$ by matching $5 \mathrm{Zr}_{2} \mathrm{Al}_{3} \mathrm{C}_{4}$ lattices with $6 \mathrm{Al}_{2} \mathrm{O}_{3}$ lattices (5/6). Therefore the $\mathrm{Zr}_{2} \mathrm{Al}_{3} \mathrm{C}_{4}$ phase can nucleate and grow on $\mathrm{Al}_{2} \mathrm{O}_{3}$ substrate. Narayan and Larson has demonstrated DME of $\mathrm{ZnO}$ on $\alpha-\mathrm{Al}_{2} \mathrm{O}_{3}(001)$, where the TEM image shows a 5/6 or 6/7 DME at the interface by inserting extra dislocations [39]. DME may also occur on $4 \mathrm{H}-\mathrm{SiC}(001)$ substrate with a $11 / 12$ or $12 / 13$ matching, which would give a misfit of less than $0.4 \%$. However, despite the low DME misfit, the direct lattice misfit still affects the quality of thin films, where a lower lattice misfit (such as for $\mathrm{SiC}$ ) gives improved crystal quality and higher phase purity, as shown in Fig. 5.

No trace of $\mathrm{Zr}_{2} \mathrm{Al}_{3} \mathrm{C}_{4}$ was found in the films grown on $\mathrm{MgO}$ and $\mathrm{YSZ}$ substrates, despite a smaller misfit compared to $\alpha-\mathrm{Al}_{2} \mathrm{O}_{3}$, indicating that the growth of the ternary phase is not solely determined by lattice matching. The condition of the substrate surface, e.g. crystal quality, roughness and surface reconstruction, can also affect film growth [40]. Usually, the surface quality of a cubic crystal cut in the [111] direction, such as $\mathrm{MgO}(111)$ and $\mathrm{YSZ}(111)$, is lower than for hexagonal and rhombohedral crystals cut in the [001] direction, due to inherent difficulties in cutting with high precision. Therefore a relatively high roughness and a high step density can easily be formed, along with an offset between [111] of the crystal and the polished surface normal. In addition, the $\mathrm{MgO}(111)$ surface is known for a very stable $(\sqrt{3} \times \sqrt{3}) \mathrm{R} 30^{\circ}$ reconstruction when O-terminated [41], which may not be completely removed after $15 \mathrm{~min}$ of heat treatment at $800{ }^{\circ} \mathrm{C}$ before the 
deposition. If so, the $\mathrm{Zr}_{2} \mathrm{Al}_{3} \mathrm{C}_{4}$ crystals were not grown on a bulk $\mathrm{MgO}(111)$ surface, but a less homogeneously reconstructed surface. On the contrary, $\alpha-\mathrm{Al}_{2} \mathrm{O}_{3}$ and $4 \mathrm{H}-\mathrm{SiC}$ substrates are generally of higher crystal quality and precisely cut surface, which favors the nucleation and growth of thin films.

\section{Conclusions}

In this work epitaxial $\mathrm{Zr}_{2} \mathrm{Al}_{3} \mathrm{C}_{4}$ thin films have been synthesized with pulsed cathodic arc, resulting in highly phase pure material on $4 \mathrm{H}-\mathrm{SiC}$ substrates. These films will allow future exploration of properties of the $\mathrm{Zr}_{2} \mathrm{Al}_{3} \mathrm{C}_{4}$. By optimizing the deposition parameters, it is possible to pursue $\mathrm{Zr}_{2} \mathrm{Al}_{3} \mathrm{C}_{4}$ thin films with higher phase purity by applying higher deposition temperature, supplying a higher Al flux ratio, and by using substrates with less lattice misfit. Also, despite flux ratios corresponding to the $\mathrm{Zr}_{3} \mathrm{AlC}_{2} \mathrm{MAX}$ phase composition were tested, no trace of this phase was observed.

$\mathrm{Zr}_{2} \mathrm{Al}_{3} \mathrm{C}_{4}$ thin film synthesis being very sensitive to flux composition, substrate temperature, and choice of substrate, is very similar to reported thin film synthesis of MAX phases. The similarities in their growth behaviors regarding $A$-element supersaturation and binary transition metal carbide intergrowth indicate a close relation between the two families of phases, despite the very different bonding environments of their $A$ elements. Previously, there has been no $M$-element in a $M-\mathrm{Al}-\mathrm{C}$ system reported for which both the MAX phase and $(M \mathrm{C})_{n}\left(\mathrm{Al}_{3} \mathrm{C}_{2}\right)$ or $(M \mathrm{C})_{n}\left(\mathrm{Al}_{4} \mathrm{C}_{3}\right)$ phase exist. However, we note that the $\mathrm{Zr}_{3} \mathrm{AlC}_{2} \mathrm{MAX}$ phase was reported [42] in parallel with the present work.

\section{Acknowledgements}

The research was funded by the European Research Council under the European Community Seventh Framework Program (FP7/2007-2013)/ERC Grant agreement no [258509]. J. L. 
acknowledges the KAW Foundation for the Ultra Electron Microscopy Laboratory in Linköping.

J. R. acknowledges funding from the Swedish Research Council (VR) grant no. 642-2013-8020

and 621-2012-4425 and from the KAW Fellowship program. The Swedish Foundation for Strategic

Research is acknowledged through the Synergy Grant FUNCASE (all authors) and the Future

Research Leaders 5 program (P.E. and J.L.).

\section{References}

[1] W. S. Williams, Transition-Metal Carbides, Prog. Solid State Chem. 6 (1971) 57-118.

[2] L. Toth, Transition Metal Carbides and Nitrides, Academic Press Inc., New York, USA, 1971.

[3] C. M. Fernandes and A. M. R. Senos, Cemented carbide phase diagrams: A review, Int. J. Refract. Met. H. 29 (2011) 405-418.

[4] U. Jansson and E. Lewin, Sputter deposition of transition-metal carbide films - A critical review from a chemical perspective, Thin Solid Films 536 (2013) 1-24.

[5] D. J. Tallman, B. Anasori, and M. W. Barsoum, A Critical Review of the Oxidation of $\mathrm{Ti}_{2} \mathrm{AlC}, \mathrm{Ti}_{3} \mathrm{AlC}$ and $\mathrm{Cr}_{2} \mathrm{AlC}$ in Air, Mater. Res. Lett. 1 (2013) 115-125.

[6] X. H. Wang and Y. C. Zhou, High-Temperature Oxidation Behavior of $\mathrm{Ti}_{2} \mathrm{AlC}$ in Air, Oxid. Met. 59 (2003) 303320.

[7] H. J. Yang, Y. T. Pei, J. C. Rao, J. Th. M. De Hosson, S. B. Li, and G. M. Song, High temperature healing of $\mathrm{Ti}_{2} \mathrm{AlC}$ : On the origin of inhomogeneous oxide scale, Scripta Mater. 65 (2011) 135-138.

[8] X. H. Wang and Y. C. Zhou, Oxidation behavior of $\mathrm{Ti}_{3} \mathrm{AlC}_{2}$ at 1000-1400 C in air, Corros. Sci. 45 (2003) 891907.

[9] X. H. Wang, F. Z. Li, J. X. Chen, and Y. C. Zhou, Insights into high temperature oxidation of $\mathrm{Al}_{2} \mathrm{O}_{3}-$ forming $\mathrm{Ti}_{3} \mathrm{AlC}_{2}$, Corros. Sci. 58 (2012) 95-103.

[10] L. F. He, Z. J. Lin, Y. W. Bao, M. S. Li, J. Y. Wang, and Y. C. Zhou, Isothermal oxidation of bulk $\mathrm{Zr}_{2} \mathrm{Al}_{3} \mathrm{C}_{4}$ at 500 to $1000{ }^{\circ} \mathrm{C}$ in air, J. Mater. Res. 23 (2008) 359-366.

[11] P. Eklund, M. Beckers, U. Jansson, H. Högberg, and L. Hultman, The $\mathrm{M}_{\mathrm{n}+1} \mathrm{AX}_{\mathrm{n}}$ phases: Materials science and thin-film processing, Thin Solid Films 518 (2010) 1851-1878.

[12] M. W. Barsoum, The $\mathrm{M}_{\mathrm{N}+1} \mathrm{AX}_{\mathrm{N}}$ Phases: A New Class of Solids; Thermodynamically Stable Nanolaminates, Prog. Solid St. Chem. 28 (2000) 201-281.

[13] Y. C. Zhou, L. F. He, Z. J. Lin, and J. Y. Wang, Synthesis and structure-property relationships of a new family of layered carbides in $\mathrm{Zr}-\mathrm{Al}(\mathrm{Si})-\mathrm{C}$ and $\mathrm{Hf}-\mathrm{Al}(\mathrm{Si})-\mathrm{C}$ systems, J. Euro. Ceram. Soc. 33 (2013) 2831-2865.

[14] N. V. Tzenov and M. W. Barsoum, Synthesis and Characterization of $\mathrm{Ti}_{3} \mathrm{AlC}_{2}$, J. Am. Ceram. Soc. 83 (2000) 825-832.

[15] K. Fukuda, S. Mori, and S. Hashimoto, Crystal structure of $\mathrm{Zr}_{2} \mathrm{Al}_{3} \mathrm{C}_{4}$, J. Am. Ceram. Soc. 88 (2005) 3528-3530.

[16] L. F. He, Z. J. Lin, J. Y. Wang, Y. W. Bao, and Y. C. Zhou, Crystal structure and theoretical elastic property of two new ternary ceramics $\mathrm{Hf}_{3} \mathrm{Al}_{4} \mathrm{C}_{6}$ and $\mathrm{Hf}_{2} \mathrm{Al}_{4} \mathrm{C}_{5}$, Scripta Mater. 2008 (2008) 679-682.

[17] L. F. He, Y. W. Bao, J. Y. Wang, M. S. Li, and Y. C. Zhou, Microstructure and mechanical and thermal properties of ternary carbides in Hf-Al-C system, Acta Mater. 57 (2009) 2765-2774. 
[18] T. El-Raghy, A. Zavaliangos, M. W. Barsoum, and S. R. Kalidindi, Damage Mechanisms around Hardness Indentations in $\mathrm{Ti}_{3} \mathrm{SiC}_{2}$, J. Am. Ceram. Soc. 80 (1997) 513-516.

[19] J. C. Schuster and H. Nowotny, Investigations of the ternary systems (Zr, Hf, Nb, Ta)-Al-C and studies on complex carbides, Z. Metallkd. 71 (1980) 341-346.

[20] L. F. He, Z. J. Lin, J. Y. Wang, Y. W. Bao, M. S. Li, and Y. C. Zhou, Synthesis and Characterization of Bulk $\mathrm{Zr}_{2} \mathrm{Al}_{3} \mathrm{C}_{4}$ Ceramic, J. Am. Ceram. Soc. 90 (2007) 3687-3689.

[21] J. Zhang, L. F. He, and Y. C. Zhou, Highly conductive and strengthened copper matrix composite reinforced by $\mathrm{Zr}_{2} \mathrm{Al}_{3} \mathrm{C}_{4}$ particulates, Scr. Mater. 60 (2009) 976-979.

[22] J. Rosen, L. Ryves, P. O. Å. Persson, and M. M. M. Bilek, Deposition of epitaxial $\mathrm{Ti}_{2} \mathrm{AlC}$ thin films by pulsed cathodic arc, J. Appl. Phys. 101 (2007) 056101.

[23] P. O. Å. Persson, J. Rosen, D. R. McKenzie, and M. M. M. Bilek, Formation of the MAX-phase oxycarbide $\mathrm{Ti}_{2} \mathrm{AlC}_{1-\mathrm{x}} \mathrm{O}_{\mathrm{x}}$ studied via electron energy-loss spectroscopy and first-principles calculations, Phys. Rev. B 80 (2009) 092102.

[24] A. Mockute, P. O. Å. Persson, F. Magnus, A. S. Ingason, S. Olafsson, L. Hultman, and J. Rosen, Synthesis and characterization of arc deposited magnetic (Cr,Mn) ${ }_{2} \mathrm{AlC}$ MAX phase films, Phys. Status Solidi RRL 8 (2014) 420.

[25] M. D. Tucker, Z. Czigány, E. Broitman, L.-Å. Näslund, L. Hultman, and J. Rosen, Filtered pulsed cathodic arc deposition of fullerene-like carbon and carbon nitride films, J. Appl. Phys. 115 (2014) 144312.

[26] PDF 00-029-1127 (4H-SiC), PDF 00-045-0946 (MgO), PDF 00-046-1212 ( $\left.\mathrm{Al}_{2} \mathrm{O}_{3}\right)$ in: PDF-2/Release 2010 RDB (Database), International Centre for Diffraction Data (ICDD), Newtown Square, PA, USA, 2010.

[27] PDF 01-074-9352 $\left(\mathrm{Zr}_{2} \mathrm{Al}_{3} \mathrm{C}_{4}\right)$ in: PDF-2/Release $2010 \mathrm{RDB}$ (Database), International Centre for Diffraction Data (ICDD), Newtown Square, PA, USA, 2010.

[28] PDF 00-035-0784 (ZrC) in: PDF-2/Release 2010 RDB (Database), International Centre for Diffraction Data (ICDD), Newtown Square, PA, USA, 2010.

[29] M. Sillassen, P. Eklund, N. Pryds, and J. Bøttiger, Effects of dopant concentration and impurities on the conductivity of magnetron-sputtered nanocrystalline yttria-stabilized zirconia, Solid State Ionics 181 (2010) 864867.

[30] Z. J. Lin, L. F. He, M. S. Li, J. Y. Wang, and Y. C. Zhou, Layered stacking characteristics of ternary zirconium aluminum carbides, J. Mater. Res. 22 (2007) 3058-3066.

[31] O. Wilhelmsson, J. P. Palmquist, E. Lewin, J. Emmerlich, P. Eklund, P. O. Å. Persson, H. Högberg, S. Li, R. Ahuja, O. Eriksson, L. Hultman, and U. Jansson, Deposition and characterization of ternary thin films within the Ti-Al-C system by DC magnetron sputtering, J. Cryst. Growth 291 (2006) 290-300.

[32] J. Emmerlich, H. Högberg, S. Sasvári, P. O. Å. Persson, L. Hultman, J. P. Palmquist, U. Jansson, Jon M. MolinaAldareguia, and Z. Czigány, Growth of $\mathrm{Ti}_{3} \mathrm{SiC}_{2}$ thin films by elemental target magnetron sputtering, J. Appl. Phys. 96 (2004) 4817-4826.

[33] PDF 01-072-9258 ( $\left.\mathrm{ZrAl}_{3}\right)$ in: PDF-2/Release $2010 \mathrm{RDB}$ (Database), International Centre for Diffraction Data (ICDD), Newtown Square, PA, USA, 2010.

[34] Z. Wang and X. Liu, Reaction in the Al-ZrO 2 -C system, J. Mater. Sci. 40 (2005) 4727-4735.

[35] L. F. He, Y. C. Zhou, Y. W. Bao, Z. J. Lin, and J. Y. Wang, Synthesis, Physical, and Mechanical Properties of Bulk $\mathrm{Zr}_{3} \mathrm{Al}_{3} \mathrm{C}_{5}$ Ceramic, J. Am. Ceram. Soc. 90 (2007) 1164-1170.

[36] R. Zhang, G. Chen, and W. Han, Synthesis, mechanical and physical properties of bulk $\mathrm{Zr}_{2} \mathrm{Al}_{4} \mathrm{C}_{5}$ ceramic, Mater. Chem. Phys. 119 (2010) 261-265.

[37] A. I. Gusev, Phase equilibria in $M-X-X^{\prime}$ and $M-A l-X$ ternary systems $\left(M=\right.$ transition metal; $X, X^{\prime}-B, C, N$, Si) and the crystal chemistry of ternary compounds, Russ. Chem. Rev. 65 (1996) 379-419. 
[38] PDF 03-065-2033 ( $\left.\mathrm{Zr}_{5} \mathrm{Al}_{3}\right)$ in: PDF-2/Release $2010 \mathrm{RDB}$ (Database), International Centre for Diffraction Data (ICDD), Newtown Square, PA, USA, 2010, vol. Newtown Square, PA, USA.

[39] J. Narayan and B. C. Larson, Domain epitaxy: A unified paradigm for thin film growth, J. Appl. Phys. 93 (2003) 278-285.

[40] J. L. Schroeder, A. S. Ingason, J. Rosen, and J. Birch, Beware of poor-quality MgO substrates: A study of MgO substrate quality and its effect on thin film quality, J. Cryst. Growth 420 (2015) 22-31.

[41] R. Plass, K. Egan, C. Collazo-Davila, D. Grozea, E. Landree, L. D. Marks, and M. Gajdardziska-Josifovska, Cyclic Ozone Identified in Magnesium Oxide (111) Surface Reconstructions, Phys. Rev. Lett. 81 (1998) 48914894.

[42] T. Lapauw, J. Halim, J. Lu, T. Cabioc'h, L. Hultman, M.W. Barsoum, K. Lambrinou, J. Vleugels, Synthesis of the novel $\mathrm{Zr}_{3} \mathrm{AlC}_{2}$ MAX phase, J. Eur. Ceram. Soc. (2015). 